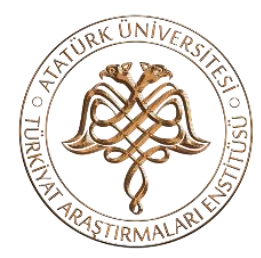

\title{
AKKOYUNLU SULTAN YAKÛB'UN ÖLÜMÜNE DAİR MÜNAZARA VE BAZI DEĞERLENDIRMELER
}
A DEBATE AND SOME EVALUATIONS ON AQ-QOYUNLU SULTAN YAKUB'S DEATH

\author{
AYŞE ATICI ARAYANCAN \\ Dr. Öğr. Üyesi Osmaniye Korkut Ata Üniversitesi, Fen Edebiyat Fakültesi, Tarih Bölümü \\ Asist. Prof. Dr. Osmaniye Korkut Ata University, Faculty of Art and Sciences, Department of History \\ ayse.atici2@gmail.com \\ iD https://orcid.org/0000-0002-4232-2564
}

Türkiyat Araştırmaları Enstitüsü Dergisi-Journal of Turkish Researches Institute

TAED-63, Eylül-September 2018 Erzurum

ISSN-1300-9052

Makale Türü-Article Types : Araştırma Makalesi-Research Article

Geliş Tarihi-Received Date : $\quad$ 28.06.2018

Kabul Tarihi-Accepted Date : $\quad 21.09 .2018$

Sayfa-Pages : $437-446$

doi : http://dx.doi.org/10.14222/Turkiyat3961

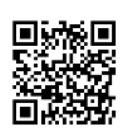

www.turkiyatjournal.com

http://dergipark.gov.tr/ataunitaed

This article was checked by

$\checkmark$ iThenticate 



\title{
ATAT̈̈RK ÏIIVERSIIIISI \\ TÜRKIYAT ARAŞTIRMALARI ENSTITÜSÜ DERGISI \\ JOURNAL OF TURKISH RESEARCHES INSTITUTE \\ TAED-63, 2018. 437-446
}

\author{
AKKOYUNLU SULTAN YAKÛB'UN ÖLÜMÜNE DAİR \\ MÜNAZARA VE BAZI DEĞERLENDIRMELER \\ A DEBATE AND SOME EVALUATIONS ON \\ AQ-QOYUNLU SULTAN YAKUB'S DEATH
}

AYŞE ATICI ARAYANCAN

\begin{abstract}
$\ddot{O} \mathbf{z}$
25 Aralık 1490 yılında ölen Sultan Yakûb'un ölümü ile ilgili dönem kaynaklarında farklı bilgiler aktarılmaktadır. Kaynaklardan bazılarında eşi yâda annesi tarafından zehirlendiğine dair bilgiler yer alırken, bazılarında taûn ( veba) gibi bir hastalığa yakalanarak genç yaşta doğal olarak vefat ettiği geçmektedir. Uzun Hasan Bey sonrası Akkoyunlu tahtına oturan Sultan Yakûb'un istikrarı sağlayıp, Akkoyunlu yönetimini tek merkezde toplamasının ardından kısa bir süre sonra zamansız ölümü Akkoyunlu Devleti'ni yavaş yavaş yıkılışa sürüklemiş, Akkoyunlu mirzaları ve aşiretler arasında taht kavgaları başlamıştır. Bu nedenle Sultan Yakûb'un ölümü devletin iç siyasetini derinden etkilemiştir. Ayrıca ölüm şeklinin yanı sıra ölümünden sonra cesedinin Şah İsmail tarafindan çıkartılıp yakılması İran ve Azerbaycan coğrafyasındaki Sünnî-Şiî mücadelesi açısından dikkat çekicidir.

$\mathrm{Bu}$ makalede Sultan Yakûb'un şaibeli ölümü, vasiyeti, ölüm tarihi, nerede defin edildiği, mezar yeri ve cesedinin akıbeti, nerede bulunduğu gibi konular ele alınırken, onun ölümünün iç ve dış siyasetteki yeri ve önemi tartışılmaya çalışılacaktır.
\end{abstract}

Anahtar Kelimeler: Sultan Yakûb, Akkoyunlu, Suikast, Ölüm, Sünnî, Şiî

\section{Abstract}

Different information about the death of Aq Qoyunlu Sultan Yakûb, who died on December 25th 1490, are reported in the related era resources. While some of the sources indicated that he had poisoned by his spouse or mother, some indicated that he had caught a disease such as a torture (plague) and died naturally at a young age. After Uzun Hasan Bey, Sultan Yakûb, who was sitting on the throne of Aq Qoyunlu, provided stability and the untimely death shortly after the Aq Qoyunlu administration was gathered in one center, the Aq Qoyunlu State was gradually dragged to the ruin.

The throne trials began between the $\mathrm{Aq}$ Qoyunlu dynasts and the tribes. For this reason, while the way that Sultan Yakûb's death deeply influenced the domestic politics of the state, the small dynasts ascend the throne with the support of the tribal leaders experienced failures successively. In addition to his way of death, after his death, his body was taken out and burned by the Safavid sultan Shah Ismail is important in terms of the Sunni-Shiite struggle between Iran and Azerbaijan.

In this article, we will try to discuss the place and significance of his death in domestic and foreign politics, while discussing issues such as Sultan Yakûb's death, date of death, where he was laid, where his cemetery was and what the fate of his body was.

Key Words: Sultan Yakûb, Aq Quyunlu, Assassination, Death, Sunnî, Shi'i 


\section{Giriş}

Sultan Yakûb, Uzun Hasan'ın ölümünün ardından Akkoyunlu devleti tahtına geçen ağabeyi Halil Sultan'a isyan edip mağlup ederek hükümdar oldu(1478). Akkoyunlu tahtında yaklaşı 12 yıl oturan ve devletin tüm birimlerini kontrol altına almaya çalışan Sultan Yakûb, Azerbaycan, Irak ve Diyarbakır'da ortaya çıkan karmaşaya son verdi. Âlimler, şairler, seyyidler gibi dönemin önemli kişilerini sarayına davet etti. (Erdem, Paydaş: 2007:130; Hüseyinzade,1394: 63). Ardından devletin sınırlarını kontrol altında tutmak ve bekasının devamı için seferlere başladı. İlk önce Kirman üzerine sefer düzenledi. 1479 yılında Karakoyunluların eline geçen Kirman bölgesine bir ordu yollayarak bölgede yeniden kontrolü sağlamayı başardı (Aka,2001: 84; Erdem, Paydaş, 2007: 131). Bu arada Urfa'yı almak isteyen Memlûklu Yaş Bek'e karşı Urfa mevkiinde zafer kazanarak, bölgede kontrol sağlamaya çalışan Memlûklerin gücünü kırdı (1480). Ardından tıpkı babası Uzun Hasan Bey gibi Gürcistan üzerine başarılı akınlar yaparak, önemli iki kale Ahıska ve Hatun Kalesi'ni ele geçirdi.(Gaffari,1334:254;Tarih-i Kızılbaşan, 2016: 35; Gülşeni,2014; 118) Bu seferin sonunda ciddi miktarda ganimetle döndü. Safevi Seyhi Haydar'ın Sirvan Sah'ına saldırması üzerine zor durumda kalan Şirvan Şahı Ferruh Yesar, Şemahi Kalesi'ne sığınarak Sultan Yakûb'tan yardım istedi. Haydar'ın bağımsız hareketinden rahatsız olan ve bölgedeki çıkarlarını korumak isteyen Sultan Yakûb, Bicanlı Süleyman Bey komutasındaki bir orduyu Ferruh Yesar Şemahi'nin yardımına yolladı. Çetin geçen savaş sonucunda Şeyh Haydar, Derbend yakınlarında yakalanıp öldürüldü, oğulları ve eşini İstahr Kalesi'ne hapsederek devleti tek çatı altında toplamayı başardı (Nevaî, 1341: 616-619; Gülşenî, 1982: 194-195; Hüseyinzade, 1394: 97; Hoca Saadettin, 1978: 344, Cemali,1377: 95, Sümer,1989: s.273). Ardından 1438 y1lında Gürcistan'a bir sefer daha düzenledi. Yönetimi sürecinde yeni yerler elde edemeyen Sultan Yakûb devletin sinırlarını babası Uzun Hasan Bey dönemindeki gibi korumayı başardı. Mısır Memlûklerinin yaptığı akını durdurup, kendisine ciddi tehlike oluşturan Safevî şeyhi Şeyh Haydar'ı öldürmesi bir süreliğine Safevî tehlikesini durdurmasına sebep oldu (Hınz,1992: 79,Handmir,1353; 432-433). Uzun Hasan Bey sonrası Akkoyunlu merkezi otoriteyi yeniden tek merkezde toplayan Sultan Yakûb, Akkoyunlu sınırlarını korumayı başarırken, yeni topraklar elde edemedi. Akkoyunlu Sultan Yakûb'un 1490 yılında henüz yirmili yaşlarda iken ansızın ölmesi Akkoyunlu sarayında şaşkınlık yaratırken, tam da devletin kontrolünün sağlandığı, istikrarın yakalandığı bir sürece denk gelmesi Akkoyunlu Devleti’ni yeniden bir karmaşaya sürükledi.

Bu makalede, Sultan Yakûb'un ölümü ile ilgili kaynaklarda geçen rivayetler doğrultusunda ölüm şekli tartışılırken Sultan Yakûb'un ani ölümünün ardında yatan siyasi sebep ve sonuçlar üzerinde durulacaktır. Nitekim Akkoyunlu Uzun Hasan Bey'in oğlu Sultan Yakûb'un tahta oturmasından 12 yıl sonra beklenmedik ölümü dönem kaynaklarına yansımış ve farklı rivayetler anlatılmıştır.

\section{Sultan Yakûb'un Ölümü ile İlgili Kaynaklarda Yer Alan Rivayetler}

Kaynaklarda Sultan Yakûb'un ölümü ile ilgili hastalık, suikast ve zehirlenme gibi farklı sebeplerden öldüğüne dair benzer olaylar anlatılırken, sultanın ölümü garip karşılanmış, şüpheyle bakılmış hatta genç yaşta ve beklenmedik ölümünden sonra 
rubailer yazılmıştır. Sultan Yakûb'un ölümü ile ilgili kaynaklarda annesinin ya da karısı tarafından zehirlendiği veya hastalanarak (veba) eceli ile öldüğüne dair birkaç farklı başlıkta bilgiler toplanmaktadır.

Dönem kaynaklarından 16.yüzyıl Safevî tarihçisi Hasan-1 Rumlu Sultan Yakûb’un annesi Selçukşah Begüm tarafindan zehirlendiğini belirtmiştir. Hasan-1 Rumlu (2006:592-593) olayları şu şekilde aktarmıştır:

“Onun ölümünün sebebi şuydu: Annesi Selçukşah Begüm, Mesih Mirza b. Hasan Padişah'ı zehirlemek istedi. Bu amaçla sulandırılmış kayısı kabına zehir kattı. Yakûb padişah, hamamdan çıkınca kardeşi Yusuf Beğ ile birlikte onu yedi. Bu sırada Selçukşah Hanım durumdan haberdar oldu. Onlara engel olmak için o da o kaysıdan yedi. Ondan sonra yatağa düştü. Yusuf Beğ ile Selçukşah Hanum öldü. Anılan yılın Safer ayının 11 'inde (25 Aralı 1490 )Yakûb Sultan padişah da bu âlemden göç etti. Ömür süresi 28 yll saltanat günleri 12 yll 2 ay idi. (Hasan-1 Rumlu, 2006: s.592-593). Ancak Hasan-1 Rumlu başka bir yerde ise Sultan Yakûb'un hastalığından bahsederken yukarıda verdiği bilgiler ile çatışmaktadır (Hasan-1 Rumlu;2006:s. 595).

Yine Osmanlı tarihçisi Hoca Saadettin'de Sultan Yakûb'un annesinin oğlu Mirza Yusuf'u tahta geçirmek için sultanı zehirlendiğine dair aktarımlarda bulunan tarihçilerdendir. Hoca Saadettin'in bu konuyu şu şekilde anlatmıştır( 1979:335) :

"Sultanın anası şehzadelerden birini yok etmek için zehirle karıştırılmış bir tas şerbet yaptırmıştı. Akıl ve ruh bakımından yoksun olmakla da bu şerbet kâsesini ihtiyatsızca ortada birakıp önemli bir iş için oradan ayrlmıştı. Bu sırada Sultan Yakûb'un kardeşi Yusuf Mirza avdan gelip saraya girdikte çok susamış olduğundan ol kâseden içip kalanını da Yusuf Mirza'ya vermişti. Ol dahi içtiği sırada anaları gelip durumu görünce acısı ile dibinde kalanı da kendisi içmiş ve üçü de ol gün birlikte ölmüşler. Bazlları Yusuf Mirza'yı fazlaca sevdiğinden ol şerbeti Yakûb Mirza için hazırladı̆̆ını ve padişahlı̆̆ Yusuf Mirza'ya devrettirmek istediğini söyler. Yakûb Mirza'nın şerbeti içtikten sonra annesi ve kardeşine de sunduğu onlarında şerbeti içmekten kaçınmayarak içmiş olduklarını anlatır. Sözün özü Sultan Yakûb ecel sakisinin elinden zehirle dolu bir kadeh ölümü çekerek yüreğinin dağladiğı 896.yılında" (Hoca Saadeddin, 1979:335) diyerek Hasan-1 Rumlu ile benzer bilgiler aktarmaktadır.

Akkoyunlu sarayını ziyarete gelen Venedikli seyyahlar ise Sultan Yakûb'un eşinin Akkoyunlu hanedanından âşık olduğu kişiyi tahta geçirmek amacı ile hazırladığı zehir sonucunda öldüğünden bahseder. Bu konuda Venedikli bir tüccarın anlattıkları ilginçtir (2017:173-174):

"Sultan Yakûb (O) Iran'ın ileri gelenlerinden birinin kızı ile evlendi. Ama bu kadın oldukça hafif meşrep bir kadın olup sarayın önde gelen beylerinden birine âşık oldu. Nihayet bu kötü kadın Sultan Yakûb'u öldürmeye karar verdi. Bu hile ile fasık adamla evlenip onu tahta oturmak istiyordu. Üstelik o Yakûb'un yakın akrabalarından biri olup, Yakûb'un oğlu olmadığından tahtın ve tacın varisi idi. Nihayet onunla tuzak kurup kocası için öldürücü bir zehir hazırladl. Âdeti olduğu üzere sekiz dokuz yaşındaki oğlu ile Itırlı hamama gitmiş olan Şah gündüz saat 22 'den akşam gün batımına kadar orada kaldı. Dışarı çıkınca hamamın yanındaki hareme geçti. Uğursuz kadın o hamamda yıkanırken içine zehir koyduğu altın şarap tası ve kadehle karşılamaya gitti. Çünkü onun hamamdan çıktıtan sonra bir şey içmek âdeti olduğunu biliyordu. Ŭ̆ursuz niyetini 
saklayamaya çalışan kadın her zamankinden daha fazla okşadl. Ama yüzünün durumuna yeterince hâkim olamadığından rengi epey uçmuştu ve bu durum Yakûb'u şüphelendirmişti. Çünkü Yakûb bundan öncede onun işlerinden bir kısmını fark ettiğinden zamanla itimadını kaybetmişti. Nihayet kadına içkiden önce kendisinin içmesini emretti. $O$ her ne kadar içince hemen öleceğini biliyorsa da kaçacak yeri olmadığından birazcı içti. Sonra altın kadehi Yakûb'a verdi. O ve oğlu geriye kalanı içtiler. Zehir o kadar tesirliydi ki gece yarısına kadar her üçü de öldü (Venedikli Bir Tüccar, 2007:173-174). Ünlü Venedik seyyah Caterino Zeno da tıpk1 diğer Venedikli tacir gibi Sultan Yakûb'un eşinin entrikaları sonucu öldürüldüğünü söylemektedir (ZenoContarini, 2006: 48).

John Woods bu konuda(Woods,1993:250-251)kaynaklarda kronoloji sorunları ve iç tutarsızlıkların yanında Sultan Yakûb'un suikasta kurban gitmiş olması ihtimali olduğu üzerinde durmakta ve 1491 yılında Şam'a ulaşan bilgilerde Sultan Yakûb'un ve akrabalarının çoğunun şiddetli bir şekilde öldürüldüğü haberinin ulaşmasını delil olarak göstermektedir (Woods,1993:250-251). Ayrıca Baba Figani Şirazi'nin Sultan Yakûb'a hitaben yazdığ 1491 yılında yazdığ 1 kasidesinin iki beytinde zehirli kupa olayına değinerek konuyu değerlendirmektedir. Baba Figani Şirazi'den aktardığı aşağıdaki beyitlere göre;

"Korkunç yazgl, sen kadehine laylk değilsin hükümdarların;

Acl şarabini toprak bir kupada sun

"Bu zevk kupası dolaşırken elden ele dedim

Tatmamallyım bu zehir dolu kâseden" Sultan Yakûb'un suikast kurban gitme olasılığı üzerinde durmaktadır (Woods, 1993:251).

$\mathrm{Bu}$ doğrultuda bakıldığında Sultan Yakûb döneminde hükümdarlık bünyesinde görev yapan, doğrudan akraba ve sultana bağlı kişilerin merkezi yönetimi ele geçirmeye çalıştı̆̆ görülmektedir. Nitekim Sultan Yakûb'un annesi Selçuk Begüm Şah saray ve hanedan işlerin yürütürken, Sultan Yakûb'un lalası Süleyman Bican Bey baş veziri olarak başkomutanlık ve yönetim divanı başkanlığı görevlerini sürdürmekteydi. Öte yandan Sultan Yakûb'un hocası Kadı İsa es-Savecî ise Akkoyunluların dini ve mali yönetimini üstlenmekteydi. Bu kişilerin her birinin oluşturduğu iktidar üssü patronaj ve kayırmacılık politikası üzerinden Sultan Yakûb'u etkileyip, merkezi denetlemek ve görev üstünlüğü elde etmek istemekteydiler (Woods,1993: 238). Dolayısıyla kesin olmamakla birlikte iktidarı ve yönetimi ele geçirmek isteyen bu kişiler yanında eyaletlerde tahta oturmak isteyen ve mirzaları destekleyen aşiret reisleri de sultan için suikast planı içerisine girmiş olabilirlerdi. Nitekim Sultan Yakûb'un ölümünün ardında Akkoyunlu ümerası kendi arasında tahtın sahibinin kim olacağı konusunda anlaşmazlıklar yaşamaya başladı ve mirzalar ve onları destekleyen aşiretler arasında tahta kimin oturtulacağına dair çatışma çıktı ve uzun süren bu süreç Akkoyunlu Devleti'nin sonunu getirdi. Aşiretler ve mirzalar arasındaki mücadele gerçeğinden yola çıkarak suikasta kurban gitmiş olma ihtimali bulunmaktadır.

Sultan Yakûb'un ölümü ile ilgili diğer bir rivayet ise doğal yolla hastalanarak Karabağ'da 1490 yılında öldüğüdür. Bu konu ile ilgili dönem kaynaklarına bakıldığında Yahya Kazvinî, Gaffarî ve Kerbelayî, Handmîr gibi müverrihlerin kaynaklarında Sultan Yakûb'un ölümü konusunda ayrıntılı açıklama yapılmazken, hastalanıp doğal yolla 
öldüğünden kısaca bahsedilir. Kaynaklarda ölüm yılı aynı verilirken, öldüğü ay Sefer (Aralık ) ya da Zilhicce (Kasım) olmak üzere farklılıklar gözlenmektedir. Yahya Kazvinî'nin Lubbu't Tevarih'ine göre (1314,223) “Gençlik günlerinde 11 Safer 898 yllında(25 Aralık 1490) tarihinde kuşladlğı Karabă̆ yurdunda öldü. Saltanat süresinin 12 yl 2 ay, ömrü 28 yll idi. Onun ölümünden iki hafta sonra kardeşi Yusuf Bey ile annesi Selçukşah Hatun bu dünyadan göç ettiler "şeklinde aktarırken suikast ile ilgili hiçbir bilgiye rastlanmamaktadır (Yahya Kazvinî, 1314:223)

Aynı şekilde Gaffarî de Sultan Yakûb'un hastalanarak öldüğünden bahsetmekte ancak Yahya Kazvinî’nin Lubbu't Tevarih'de aktardıklarının tersine önce annesi ve kardeşinin öldüğünü sonra onun vefat ettiğini yazmaktadır. Gaffarî şu şekilde aktarır (1334:254): "Karabă̆ gidip Sultan yurdunda ikamet yükünü koydu. O sirada annesi rahatsızlanıp 28 Zilhicce 895 (4 Kasım 1490 ) yılında öldü. Kardeşi Yusuf Bey ile kendisi hasta idi. Annelerinin ölüm haberi saklandı. Sonunda Aşure olan Cuma gecesi Yusuf Bey öldü. Onun ölüm haberini de gizli tuttular. Yakûb Bey'in hastalı̆̆l günden güne artmaktaydl.11 Safer 896 (25 Aralk 1490) Perşembe ikindi vakti vefat etti (Gaffarî,1334:254) Budak Münşî Kazvinî (2000: s.86) "Ömrünün baharın görmedi, 28 yaşında vefat etti, 896 (1490) yllinda, 12 yll süresince saltanat sürdügünden” bahseder. İsfahân-î Kazvinî, Hold-î Barin adlı eserinde ise ömrünün baharında otuza yaklaşırken 11 Safer 1490 y1lında, Karabağ kışlağında öldüğünü belirtenlerdendir. 28 yıl ömrü, 12 yıl 2 ay saltanat sürdüğü şeklindeki açıklamasında diğerleri ile benzer bilgiler görülmektedir (İsfahân-î Kazvinî, 2001: 724)

Sultan Yakûb döneminin en önemli müverrihlerinden İsfahanî Tarih-i Âlem Aray-i Emini adlı eserinde belalı bir hastalığın saraya geldiğinden bahseder ve sultanın taûn hastalığından öldüğünü aktarır. Karabağ kışlağına ise taûn hastalığının ansızın geldiğini ordugâhı ve komşu başkentlere de yayıldığından söz eder (İsfahanî, 2003:s.369, Minorky, 1957:s.107). Yine Sultan Yakûb'un annesi tehlikeli bir hastalığa düştü. 1490 yılında bir kaç gün sonra öldü. Annesinin ölümünden bir kaç gün sonra Yusuf bahadır onu ziyarete gittiğinde bu durumdan sıkıntıya düştü ve hastalık onun bütün damarlarına nüfuz etti ve öldüğünü söylerken, ardından Karabağ'daki ordugâhta giderek hastalandı ve kadere teslim oldu şeklinde aktarımına devam eder (İsfahanî,2003:s.401402;Minorky,1957:s.110). Başka bir yerde ise Yakûb'un annesini ziyarete gitmesi hastalığını hızlandırdı ve ölümün pençesine düşürdüğünü dile getirirken, 11 Safer 896 /24 Aralık 1490 yılında bu dünyadan ayrıldı şeklinde geçmektedir (İsfahanî, 2003: s.401-402; Minorsky, 1957: s.111). Hafız Kerbelayî de benzer bilgiler aktarırken hastalanarak öldüğünü belirten ortaçağ müverrihlerindendir.( Kerbelaî-i Tebrîzî, 1383:)

Benzer bilgileri Handmîr Habibü's Siyer adlı eserinde Yakûb Mirza'nın Karabağ Arran mevkiinde ordugâhta iken belanın geldiğinden, Sultan menzilinde bulunduğu 896(1490) yılının kış mevsiminde ilk önce Yusuf Mirza'nın hastalanıp öldüğünü, annesinin ise daha matem merasimini tamamlamadan ahiret âlemine göç ettiğini, aynı hafta içinde de Yakûb Mirza'nın ahirete göçtüğünü belirtir (Hândmîr,1353:436). Ayrıca Sultan Yakûb'un Tebriz'de yayılan veba salgınıyla uğraştı̆̆ını ve bir süre sonra 1490 Aralık (H.896 Sefer ayında) Karabağ'da öldüğünü belirtir (Handemir, 1353:35).Dönem kaynaklarından Tarih-i Kızılbaşan'da Karabağ kışlağında hastalandığını yazmaktadır (Tarih-i Kızılbaşan, 2016: 35) Sultan Yakûb'un çok yakınında bulunan Gülşenî ise onun 
doğal olarak öldüğ̈̈nden bahsedenlerdendir. "Sultan Yakûp 12 yll, iki ay saltanat etti"(Gülşenî, 2014: 383), “olay Karabağ'da intikal etti” şeklinde kısaca ve üstü örtülü konuya değinir (Gülşeni,2014:188). Akkoyunlu sarayına yakın olan Gülșenî ve İsfahanî’nin Sultan Yakûb'un ölümü daha sessiz bir şekilde anlatması ve suikasttan bahsetmemesi ölüm olayının gerçekleşme sürecini sorgulatmaktadır.

Bitlisi'nin Şerefname'sinde ise yukarıdaki kaynaklara benzer ifadeler yer almış, Sultan Yakûb'un kardeşinin ve annesinin Karabağ kışlağında hastalığa yakalandığını, annesinin 8 Zilhicce günü öldüğünü, fakat onun ölüm haberinin iki kardeşten, hastalıkları şuasında gizli tutulduğunu, 1491 yılının Muharrem Cuma gecesi Sultan Yakûb'un kardeşi Yusuf Bey'in öldüğünden bahseder. Sultan Yakûb'un da hastalığının giderek ağırlaştığını ve sonunda Safer ayında Perşembe günü ikindi vakti babasından, anasından ve kardeşinden sonra beka diyarına göç ettiğine dair bilgiler verirken diğer kaynaklar gibi hastalanarak öldüğünden bahseder (Bitlisi,1971:130-131).

Sultan Yakûb'un hazin, ani ve genç yaştaki ölümü devlet erkânı aşiret reisleri ve hanedan için beklenmedik bir ölüm olarak karşılanırken, dönemin şairlerinin şiirlerine ve rubayilerine yansıyacak kadar etkili olmuştur. Nitekim Horasanlı ünlü bir şair Sultan Yakûb'un ölümünden sonra şu rubaiyi yazmıştır:

"Bir ömür kalbim Yakûb'un sevgisi ile çarptı;

Yakûp gitti, Yakûb’un yüzünü görmedi.

Yakûb'un gamindan bana gelen sıkıntiyı hiçbir zaman Yakûb,

Yusuf'un üzüntüsünden çekmedi"'(Hasan-1 Rumlu, 2006: 594)

Yine Hasan-1 Rumlu'nun aktarımından (2006:595) Kadı Alladdin'in Sultan Yakûb'un ölüm olayı hakkında şu rubailer yazılıdır:

"Pazartesi rüyamda cennet bahçesinden

Yusuf ve Yakûb'u yan yana gördüm.

Her ikisinin vefat tarihini sordum;

Dedi ki "Huld-i berin"den başka ne söyleyim"(Hasan-ı Rumlu, 2006: 595)

Aynı şekilde Hoca Saadeddin Efendi'nin Tâcüt Tevârih'inde geçen "Mevlana Benayi bu tarihlerde Horasan'a gelmiş ve Sultan'ın hizmetine girmekle mutluluk bulmuştu. Bu olmayacak olay karşısında gönlünce şöyle demişti:

Ne Yusuf'un bir Nişan gördüm ne de Yakûp'tan bir iz

Allah Yakûp'a ni'ttiyse Yusuf'a da öyle etti. (Hoca Sadettin Efendi,1979: 335)

İsfahanî, Yahya Kazvinî, Bitlisî, Gülşenî gibi müverrihler doğal yollar ile hastalanıp öldüğ̈nü aktarırken, Hasan-1 Rumlu, Hoca Saadettin ve Venedikli Seyyahlar gibi dönemi aktaran diğer kaynaklardan bazılarında zehirlenerek öldürüldüğüne dair rivayetler anlatılmakta. Sonuç olarak 1487-1490 y1lları arasında Azerbaycan'da veba veya taûn salgını oldukça arttığını görmekteyiz. Altı ay gibi kısa bir süre de Sultan Yakûb'un sarayındaki önemli kişilerin hayatını bu hastalıktan dolayı kaybetmesi Akkoyunlu yönetimini çıkmaza soktu (Faruk Sümer, (1989; s.274; Woods,1993,s.250). Dolayısıyla Akkoyunlu hanedanındaki küçük yaştaki mirzalar ve Bicanlu, Musullu gibi büyük aşiret reisleri devlet yönetimde etkili olmaya başladı. Bu da bazı devletin merkezi otoritesinin çok hızlı bir şekilde çözülmesine sebep oldu.

Sultan Yakûb'un ölümü ile ilgili kehanetlerde de bulunuldu. Bunlardan dönemin önemli dervişlerinden ve Akkoyunlu sarayında Sultan Yakûb'a çok yakın olan İbrahim 
Gülşenî gayb-i bilme ve ölüm tarihleri konusunda bazı kehanetlerde bulunur. $\mathrm{Bu}$ kehanetlerden biri de Sultan Yakûb'un ölümünü rüyasında görmüş olması hatta ona haber vermesiydi. Nitekim Sultan Yakûb haberden 12 gün sonra hakkın rahmetine kavuştu (Gülşenî, 2014:283; Konur, 1998: 90). Aslında İbrahim Gülşenî’nin bu kehaneti Sultan Yakûb'un moralini bozdu ve hasta yatağında mücadele veren sultanın yaşama istediğini kıran etmenlerden biri olduğuna dair yorumlar yapılmakta (Woods,1993: s.252).

Kaynaklarda geçen bütün bu anlatılanların sonucunda Sultan Yakûb'un hastalığı ve ölümü her ne şekilde olursa olsun, onun sonrasında devletin aşiret-bürokratik ikili yapısında çözümlenememiş gerginlikler ve iç politikadaki çekişme üst üste binerek devleti temellerinde sarsarak çöküşe doğru sürükledi (Woods,1993: s.203). Ayrıca istikrarsız bir yönetim tarzı oluşan devletin hukuki ve fiili bölünmesinin sonucunda Safevîler karlı çıkarak Şiî inancını temel alan yeni bir devlet kurmayı başardı. Bu başarıda Akkoyunlu hanedanın ve aşiretlerin kendi arasında verdiği mücadele esnasında pek de fark edemedikleri, gizliden güç kazanan Safevîleri durdurmaları zor oldu.

\section{Sultan Yakûb'un Defin Yeri ve Akıbeti}

Sultan Yakûb'un önce Karabağ sonra Tebriz'e defin edildiği kaynaklarda geçmektedir. Sultan Yakûb öldükten sonra cenaze merasimi için hazırlıklar yapıldı. Cenaze kefenlendikten sonra ilk önce Karabağ gömüldü. Daha sonra Tebriz'e taşınarak, Nasiriyye Cami avlusuna yeniden nakil edilip, defin edildi. Her ne kadar bu dünyadaki mekânı Nasiriyye Cami avlusu olarak kaynaklarda geçse de İsfahanî eserinde "Büyük sultan en yüksek cennet olan firdevs-i barın'a taşındi" diyerek son mekânı cennete gittiğini vurgulamak istemiştir. (İsfahanî, 2003: s.401-402; Minorky, 1957: s.111)

Sultan Yakûb'un ölümü hususuna ilaveten onun öldükten sonra mezarından çıkartılıp yakılması yâda akıbeti de incelenmesi gereken hususlardandır. Safevî kaynaklarının bazılarında Sultan Yakûb'un ölümünü Şeyh Haydar'ın öldürülmesi ve Safevilere yaptıklarından dolayı cezalandırdığı ve bu nedenle öldüğ̈̈ne inandıklarına değinirler (Yahya Kazvinî,1314: 391; Gaffarî,1334: 26, Anonim,1971:26-29). Nitekim 1506 yılında Safevî sultanı Şah İsmail, Dulkadirliden Korçubaşı Dede Abdal Bey, Şeyh Haydar'a karşı savaşanların tespit edilip,katl edilmesi için Taberistan'a gönderildi. Bu sırada Türkmen kabilelerine mensup çok sayıda adam öldürüldü (Gündüz, 2010: 33). Ayrıca Şah İsmail, Tebriz'de Safevî tahtına oturduktan sonra Şeyh Haydar'ın intikamını almak için büyük katliamlar yaptı. Bu nedenle Sultan Yakûp ve Şeyh Haydar arasında yapılan Derbend Savaşı'na katılanları tespit edip, hepsini öldürttüğü kayıtlarda geçer' ${ }^{1}$. Hatta başta Sultan Yakûb'un mezarı olmak üzere savaşa katılıp ölen beylerin bile

\footnotetext{
${ }^{1}$ Şeyh Haydar Şirvanşahların üzerine sefer düzenledi. Şamahı’yı ele geçirip, Demirkapıyı kuşattı. Şirvanşahlı Ferruh Yesar damadı Sultan Yakûp'tan yardım isteyince, Biçenli Süleyman Bey’i kalabalık bir ordu ile Azerbaycan'a yolladı. Bu sırada Derbend'i kuşatmakta olan Şeyh Haydar kuşatmayı kaldırıp orduyu karşılamaya gitti. Tabersaran'da Süleyman Bey'in komutasındaki Akkoyunlu ordusu ile yapılan savaşta Şeyh Haydar başına isabet eden bir ok ile öldürüldü(1488).Cesedi Taberseran'a gömüldü ve başı kesilerek Tebriz’e getirildi. (Gülşenî, 1982:194-195; Nevaî,1341:616-619) Şah İsmail daha sonra babasının mezarını Erdebil'e taşıttı ve üzerine bir türeb yaptırdı.(Hinz,1992: 76) Sokaklarda iki gün teşhir edildikten sonra Tebriz meydanında köpeklerin önüne atıldığ kayıtlarda geçmektedir (Gündüz, 2010:33-34)
} 
mezarlarından çıkartıp yaktırdı(Venedikli Bir Tüccar, 2007:183-185; İsfahanî, 2003:402; Woods,1993:300 ).Uzun Hasan Bey'in soyu ve Bayındır aşireti Şarur ve Alma-kulak'ta Şah İsmail'in katliamına uğrayanlardandır. Dahası Bayındırların ölüleri ve doğmamış çocukları Şah İsmail'in kurbanı oldular. Tebriz'de Şah İsmail, Sultan Yakûb ve diğer ölülerin mezar çıkartıp yakılmasının yanında tüm hamile Bayındır kadınlar ve prenslerinin öldürülmesini emretti. Şeyh Haydar'ın gazabından kaçabilen Bayındırlar arasında İran'da kalmayı tercih edenler yeni bir yap1 ve bağımlı statü ile kaldılar(Woods,1993: 300). Bu olaylar öç almanın yanında Akkoyunlu Devleti'nin yıkılıp, yerine giderek güç kazanan Şiîliğin itibar gördüğü yeni bir sürecin başlaması ile birlikte Safevî Devleti'nin kurulmasına neden oldu. Öte yandan Şah İsmail, Bayındır mensuplarını etkisiz hale getirdikten sonra yeni dinsel bir kopuş, yeni bir siyasi ideoloji kurdu (Woods, 1993:300-3002).

\section{Sonuç}

Akkoyunlu Sultanı Yakûp kısa hükümdarlığı süresince devletin başına geçip tek çatı altında toplaması Akkoyunlu Devleti'nin bir süre daha devamlılı̆ını sağladı. Öte yandan suikast ya da hastalanarak öldüğüne dair kaynaklarda geçen rivayetler devletin son dönemlerinde ortaya çıkan entrikalara ve olaylara açıklık getirmesi açısından önemlidir. Suikasta kurban gitmesi ya da hastalanarak ölmesi devletin iktidar güçleri ve aşiretleri arasında çıkan ve süregelen taht mücadelesini aydınlatırken, Sultan Yakûb'un ölümünün ardından Akkoyunlu Devleti'nin yavaş yavaş yıkılışa sürükleyen süreci başlatması açısından sonun başlangıcı oldu. Sultan Yakûb'un ölümünün ardından aşiret beylerinin iktidar kavgası ve çocuk yaştaki mirzaların tarafgirliğini yaparak tahta oturtup, gücü ellerinde tutmaya çalışmaları devleti güçsüz duruma soktu, istikrar bozuldu. Dolayısıyla Sultan Yakûb'un ani ölümü Akkoyunlu sarayında karmaşaya neden olurken, kontrolün tam sağlanamadığı bu süreçte Safevi Devleti'nin kurulmasının yolunu açtı. Safevi Devleti'nin kurulması ile birlikte sert bir şekilde geçmişin öcü alınarak, sultanın mezarına bile zarar verilmesi aynı coğrafyada yeni kurulan devletin politikasının Akkoyunlu Devleti'ne göre daha sert ve katı bir siyaset benimsediğinin de kanıtıydı. Ayrıca Sünnî devlet politikasından Şiî devlete geçişin de başlangıcı idi. Keza Sultan Yakûb döneminde ve sonrasında saray etrafinda bulunan tüm tasavvuf ehl-i, tarikat şeyhleri ve dervişleri ya öldürüldü ve hapis edildi yâda göçe zorlandı. Bu da Yakındoğu ve İran'da dini açıdan Şiîliğin yerleşmesine zemin hazırladı. 


\section{Kaynaklar}

Aka. İsmail. (2001). Iran'da Türkmen Hâkimiyeti. TTK: Ankara

Anonim(2016). Tarih-i Kızılbaşan. Çev. Tufan Gündüz. Yeditepe Yayınevi: İstanbul

Anonim. (1349/1971) Alem-âra-yı Şah İsmail. Nşr. Asgar Muntazer Sahib. Tahran

Budak. Münşi Kazvînî. (2000). Cevâhirü'l-ahbar: Bahş-i Tarih-i İan az Karakoyunlu ta Sal1984. haz. Behram Nejad. Merkez-i Neşr-i Miras-1 Mektub: Tahran

Bitlisi. Şerefhan. (1971). Şerefnâme. Çev. E.Emin Bozarslan. Çıra Yayınları: İstanbul

Cemali. Dr. Muhammed Kerim Yusuf. (1372). Teşkil-i Devlet-i Safevi ve Ta'mim-i Mezheb-i

Teşyyu-i Devâzdeh-i İmâmî be Unvan-1 Tenha Mezheb-i Resmî. Emir Kebir: İsfahan

Erdem. İlhan-Paydaş. Kazım. (2007). Akkoyunlular. Birleşik Yayınevi: Ankara

Gaffârî. (1334). Tarih-i Cihân-âra. Nşr. Hasan Neraki . İntişarat-1 Kitap: Tahran

Gündüz. Tufan. (2010). Son Kızllbaş Şah İsmail. Yeditepe Yayınev: İstanbul

Hasan-1 Rumlu. (2006). Ahsenü't Tevarih. Çev. Mürsel Öztürk. TTK: Ankara

Hândmîr El-Hüseynî. ( 1353/1975). Tarih-i Habîbü's-Siyer fi Ahbar-ı Efrad-ı Beşer. haz.

Muhammed Debîr-siyakî. İntişarat-1 Kitab Furuş-i: Tahran

Hınz. Walther. (1992). Uzun Hasan ve Şeyh Cüneyd XV. yüzyllda Iran'ın Milli Bir Devlet Haline Yükselişi. çev. Teyfik Biyıkoğlu. TTK: Ankara

Hüseyinzade. Hadi Seyid. (1394). Tarih-i Feramosh Shode:Iran Der Dovre-i Sultan Yakub Akkoyunlu. Neşr-i Tarih-i İran:Tahran

Hoca Sadettin Efendi. (1979). Tâcüt Tevârih. Haz. İsmet Parmaksizoğlu. C.III. Kültür Bakanlığı Yayınları: İstanbul

İsfahânî. Fazullâh ibn Rûzbihân Huncî. (2003). Tarih-i Âlam Ârây-ı Emînî. haz. Muhammed Ekber Aşik. Miras-1 Mektub: Tahran

Kazvinî. Muhammed Yusuf Vâleh-i Îsfahânî-yi. (2001). Hold-i Berîn (Târîh-i TimûriyânTürkemenân). haz. Mirza Haşim Muhaddis. Miras-1 Mektub: Tahran.

Kazvînî. Yahyâ Abd'ül-latif El-Hüseynî. (1314). Lübbü't Tevârih. haz. Seyyid Celaleddin Tehrani. Tahran

Hüseyin Hafiz Kerbelâ̂-i Tebrîzî (1383). Ravzatu'l Cinân ve Cennâtü'l Cenân. C.I-II. yay. Cafer Sulan El-Kurraî. :Tahran

Konur. Himmet. (1998). İbrahim Gülşen̂̂ (Hayatı. Eserleri. Görüşleri. Yayınlanmamış Doktora Tezi. D.E.Ü. Sosyal Bilimler Enstitüsü: İzmir

Minorsky. W. (1957). Persian in A.D. 1478-1490 An abridged of translation of Fadlullah b.Ruzbihan Khunji's Tarikh-i Alam-Ara-yı Aminî. The Royal Asiatic Society of Great Britian And İreland: London

Muhŷ̂-yi. Gülşenî. (2014). Menâkab-ı İbrâhim-i Gülşenî. haz. Mustafa Koç. Eyyüp Tanriverdi. Bilnet Matbaacilik: İstanbul

Nevai. A.(1341). Esnâd ve Mukâtebât-ı Tarihî-yi Iran ez Timur ta Şâh İsmail. Tahran: Bungah-1 Tercüme ve Neşr-i Kitap

Sümer. Faruk (1989). “Akkoyunlular”. DİA. C.2. Türk Diyanet Vakfi Yayınları: İstanbul. ss. $273-274$.

Zeno. Caterino-Contarini Ambrogio. (2006). Uzun Hasan-Fatih Mücadelesi Döneminde Doğu'da Venedik Elçileri. Çev. Tufan Gündüz. Yeditepe Yayınevi: İstanbul

Woods. John. (1993). 300 Ylllı Türk Imparatorluğu Akkoyunlular. Milliyet Yayınları: İstanbul. 
